\title{
Searching for the concept of staff training for public administration in Poland
}

\begin{abstract}
Research on the functioning of public administration is interdisciplinary. The analysis of the functioning of public administration requires a systemic view in which the system of relations between the entire system and individual subsystems of public administration on the one hand and its external environment on the other is an important element. This approach comes from the management sciences. It is reflected in the science of administration. The social subsystem is a particular subsystem of public administration requiring an interdisciplinary approach. In the Polish system of public administration, the social subsystem consists of employees forming the civil service corps and other staff employed in offices and other public administration structures. Formation of the administration staff is associated not only with the recruitment of properly educated candidates for work in the offices of public administration bodies. It is very important to shape appropriate ethical attitudes of officials of both government and local government administration. They should know the rules of official ethics. However, it is not possible to codify all the ethical standards of a public administration employee, so the general standards of the moral law should be applied in this respect. Currently, graduates of higher education studies preparing for work in administration are generally adequately prepared for analysing normative acts, issuing administrative decisions or understanding the rules of the legal system in general, but they lack the basis for addressing to a sufficient extent the issues related to ethics of acting and respecting the values adopted in the society.
\end{abstract}

Keywords: official service corps, official ethics, moral standards, studies' curriculum

1 Prof. Stanisław Wrzosek - John Paul II Catholic University of Lublin, Faculty of Law, Canon Law and Administration; e-mail: wrzosek@kul.pl; ORCID: 0000-0001-5557-5758. 


\section{Public administration as an interdisciplinary object of interest}

Research on the functioning of public administration is increasingly interdisciplinary. It requires a systematic approach in which the subsystem of organisational goals and values is an important element. The approach to public administration as an organisation requires looking at it not only from the point of view of the science of administrative law, but also the use of other disciplines related to the classical set of administrative sciences, namely administration and administrative policy. The disciplinary approach requires even going beyond the field of legal sciences and basing on considerations related to the field of social sciences and the field of economic sciences, in particular management sciences. What should be pointed out in particular in this respect is the goal (or rather the goals) of public administration that is (are) directly related to its mission. This is a very good example of a public administration subsystem that can be analysed from the point of view of various scientific disciplines. This is due to the fact that it is determined by means of normative acts that are included in the field of interest of the science of administrative law (as its source). This issue may also be - or rather should be - analysed from the point of view of the science of administrative policy, both administrative policy defining the role of administration in the structure of the state and administrative policy defining how the administration is to carry out the role entrusted to it in the state. Then comes the question of the effectiveness of implementation of the goal set before the administration, and this issue requires a look from the point of view of the science of administration, which uses the achievements of management sciences to an increasing extent.

The analysis of the functioning of public administration requires a systemic view in which the system of relations between the entire system and individual subsystems of public administration on the one hand and its external environment on the other is an important element. This environment is comprised of both whole communities and individual citizens or their groups and all other entities that are parties to administrative proceedings or in any other way affect the administration or whose situation is determined by the administration. Addressing the issue of the reception of administration activities by its social environment is an important element of research related to the search for optimal solutions in the delivery of the mission implemented by it. What is needed in this respect is, first and foremost, a view that includes analysing the administration's use of legal forms of action. 
However, this is not enough and the regulations of substantive administrative law should also be included. The procedural regulations are a consequence of the regulations contained in substantive law.

The social subsystem is a particular subsystem of public administration requiring an interdisciplinary approach. Admittedly, the competences in the legal sense are assigned to public administration bodies, but every decision related to the implementation of these competences requires its preparation, and this belongs to the sphere of tasks of an office that is the auxiliary apparatus of the body. In this respect, the science of administration distinguishes a formal decision-maker, who has discretion to take the decision in the legal form of administration action, and a material decision-maker, who has discretion to prepare the indicated decision.

\section{The staff of public administration as its social subsystem}

In the literature on organisation and management theory, it is argued that the social subsystem of an organisation, or people, is the most important and distinctive organisation's component that is distinct from other subsystems. Other subsystems, for example goal, structure or technique subsystems, are only artificial subsystems. They are defined and created by the social subsystem and are considered to be instruments of the social subsystem. ${ }^{2}$ As a result, in the management sciences, as well as in the administration sciences connected with them, a great emphasis is placed on social issues, both in the vertical system, i.e. an employee (an official) and their superior (e.g. an administration body that is also the head of the office), as well as in the horizontal system, i.e. an employee and other people employed at the same level in the organisation (office) as them. In management sciences, matters related to social issues in an organisation are referred to as "human resource management". Human resource management is understood in these sciences as "activities of an organisation aimed at attracting, developing and maintaining an effective labour force". ${ }^{3}$ The term "labour force" may not be appropriate for administration, but the meaning of the cited definition reflects the nature of the social subsystem.

The management of the social component, also referred to as human resource management, concerns the following issues:

$\square$ the effects of a change in management aimed at supporting a flexible approach to the acceptance of new workplace practices;

$\square$ generating a large contribution to organisational development;

2 A.K. Koźmiński, W. Piotrowski (eds.), Zarządzanie. Teoria i praktyka, Warszawa 1998, p. 56.
3 R.W. Griffin, Podstawy zarządzania organizacjami, Warszawa 1996, p. 419. 
being normative (prescriptive) and undertaking new activities as opposed to being full of respect for labour law, which is typical of personnel management;

$\checkmark$ defining labour relations by creating an organisational culture conducive to co-operation and commitment;

$\square$ adopting a long-term point of view to integrate human resources into a coherent whole;

emphasising the need for direct communication;

$\checkmark$ development of organisational culture;

encouraging employees to participate in working groups;

$\square$ developing employees' skills in the long-term perspective, not focusing solely on their current duties and scope of responsibilities. ${ }^{4}$

Most of the above-mentioned issues can certainly be related to the management of the social subsystem in public administration, in particular the issue of flexible approach to new workplace practices, adopting a long-term point of view to integrate human resources into a coherent whole or developing employees' skills in the long-term perspective. ${ }^{5}$ When considering the social aspect in public administration, it is necessary to signal the division of structures in organisations into formal, informal and non-formal ones, but only formal structures have an actual significance in the implementation of the mission in modern administration. In the case of administration, the existence of informal and non-formal structures is not conducive to the success of the whole, which is the public administration system. In the case of this system, the functioning of formal systems is required, which Max Weber was one of the first to advocate in his conception of a bureaucratic model of administration.

In the Polish system of public administration, the social subsystem consists of employees forming the civil service corps and other staff employed in offices and other public administration structures. In the literature, the notion of administration staff is understood as "persons performing activities related to the functioning of public administration and administrative activities in state offices other than administrative units regardless of the method of establishing an employment relationship with them". ${ }^{6}$

4 J. Sutherland, D. Canwell, Klucz do zarządzania zasobami ludzkimi. Najważniejsze teorie, pojęcia, postaci, Warszawa 2007, pp. 296 et seq.

5 S. Wrzosek, System administracja publiczna. Systemowe determinanty nauki administracji, Lublin 2008, p. 52 .

6 E. Ura, E. Ura, Prawo administracyjne, Warszawa 2006, p. 257. 
The success of the implementation of state tasks referred to as administration depends on the form of "the system composed of people organised for a permanent, systematic, future-oriented implementation of the common weal as a public mission, involving mainly (but not exclusively) the current implementation of laws equipped for this purpose with state authority and material and technical resources". ${ }^{7}$ The above-mentioned formation of the administration staff is associated not only with the recruitment of properly educated candidates for work in the offices understood as an auxiliary apparatus of public administration bodies. It is very important to shape appropriate ethical attitudes of officials of both government and local government administration.

\section{Influence of the internal environment of the administration on the implementation of its mission}

The issue of the ethics of officials from the point of view of the science of administration should be defined as by far the most important element of the internal environment of the administration. Interest in this issue is reflected not only in the science of administration, but also in other fields of knowledge, and above all in the field of philosophical sciences. As part of these sciences, ethics as a scientific discipline belongs to the field of philosophical practical sciences. Ethics is characterised by normative ethics and descriptive ethics. ${ }^{8}$ From the point of view of shaping modern public administration, normative ethics is more important, although from the point of view of detecting the regularities of the development of official ethics, analyses conducted as part of descriptive ethics are also important. "Official ethics as a separate scientific discipline is normative. It can be exercised in at least three approaches: procedural, artheological and integral one". ${ }^{\prime 9}$ Three types of sources

7 Definition of administration by I. Lipowicz (Z. Cieślak, I. Lipowicz, Z. Niewiadomski, Prawo administracyjne. Część ogólna, Warszawa 2002, pp. 27 et seq).

8 "Normative ethics deals with determining what is morally good and what is wrong, what is obligatory and what is prohibited, and - on the basis of accepted assessments of related obligations - with setting specific directives, i.e. standards of morally positive behaviour, and indicating ways for such a transformation of common morality that adapts it to the accepted moral ideal; it is formulated in various language structures and in various worldview and philosophical contexts, addressed to various recipients, formulated in general and specific issues [...] Descriptive ethics deals with the description and explanation of the accepted (common) morality in various epochs and social environments, indicating the sources, structure, function of morality as a form of social awareness and identification of development regularities." (R. Wiśniewski, Etyka, [in:] Wielka Encyklopedia PWN, Vol. 8, Warszawa 2002, p. 393).

9 T. Barankiewicz: Etyka urzędnicza - pojęcie, [in:] M. Domagała, A. Haładyj, S. Wrzosek (eds.), Encyklopedia prawa administracyjnego, Warszawa 2010, p. 284. According to this author, ethics in procedural 
of official ethics have been distinguished, namely: 1) standards incorporated into the legal system; 2) standards not incorporated into the legal system (declarations, resolutions); 3) non-code standards (social morality). ${ }^{10}$

The literature states that "the most known ethical codes of the public service containing a catalogue of basic values that public officials should observe include the Nolan Principles developed in Great Britain". ${ }^{11}$

These principles, referred to as the "Seven Principles of Public Life" were formulated in the Nolan Report. ${ }^{12}$ The concept of ethics in public life suggested by the Nolan Committee consists of the following seven principles:

1) Selflessness - an order to be guided solely by public interest;

2) Integrity - holders of public office must not act to gain personal financial or material benefits and benefits of their family or friends;

3) Objectivity - holders of public office must act and make decisions impartially, fairly and on merit, using the best evidence and without discrimination or bias;

4) Accountability - holders of public office are accountable to the public for their decisions and actions and must submit themselves to the scrutiny necessary to ensure this;

5) Openness - holders of public office should act and take decisions in an open and transparent manner;

6) Honesty (now: an order of truthfulness) - holders of public office are obliged to report any private interests related to their duties and to take steps to resolve any conflicts that arise in a manner that protects the public interest;

7) Leadership - holders of public office should exhibit these principles in their own behaviour. ${ }^{13}$

The above-mentioned principles should be considered not only from the point of view of morality or the sensitivity of the conscience of public administration staff.

terms is associated with defining the basic principles and values shaping the high quality of public administration activities; ethics in the artheological perspective is related to the search for a personal model of an official who is desirable from the point of view of public administration; an integral approach combines procedural and artheological approaches (ibidem, p. 284). Ibidem.

11 D. Sześciło, A. Mednis, M. Niziołek, J. Jakubek-Lalik, Administracja i zarządzanie publiczne. Nauka o wspótczesnej administracji, Warszawa 2014, p. 215.

12 Nolan Report was elaborated by the Committee on Standards in Public Life established by the Prime Minister of Great Britain in 1994. For more see: P. Skuczyński: Infrastruktura etyczna administracji publicznej, [in:] System prawa administracyjnego, Vol. 13: R. Hauser, Z. Niewiadomski, A. Wróbel (eds.), Etyka urzędnicza i etyka stużby publicznej, Warszawa 2016, pp. 119 et seq. 
They should also be taken into consideration when considering the effectiveness of the administration's functioning, i.e. from the point of view of the science of administration, which has its roots in the theory of organisation and management. The above-mentioned statement that ethical principles should also be considered from the point of view of achieving the success of the public administration mission is based on the conviction of the indissolubility of the behaviours and value systems of the organisation's participants with the analysis of other organisational, economic or legal factors.

The legal factors are primarily related to the ways of strengthening and consolidating the behaviours of an administrative employee. In addition to sensitising employees' consciences, two most common ways are indicated in this respect: (a) developing and popularising ethical codes of a public administration employee, (b) inclusion of ethical standards of a public administration employee in the rules of established law. ${ }^{14}$ Therefore, the issues related to official ethics must not be separated from the implementation of public administration tasks. The implementation of this mission depends on the manner of conduct of the administration employee and in particular on how they understand the ways to achieve the intended goal. Therefore, ethical issues as an element of the internal environment should certainly be taken into account when considering issues related to the effectiveness of achieving public goals by the organisation (i.e. the system) that is public administration.

The indicated ethical issues in public administration activities are related to the "right to good administration". The right to good administration, originating from the Charter of Fundamental Rights of the European Union, and in particular Article 41(1), which reads "Every person has the right to have his or her affairs handled impartially, fairly and within a reasonable time by the institutions, bodies and agencies of the Union", ${ }^{15}$ is an important guideline for shaping the attitudes of public administration employees. It does not mean in the contemporary sense only a set of powers giving rise to the obligation for the authorities to act in accordance with the law. ${ }^{16}$ Certainly, the work of people employed in administration, regardless of whether they perform functions of bodies or are ordinary office employees, must be ethical behaviour, and therefore must be honest, integral and accountable.

In the literature on the science of administrative law, there is an indissoluble link between official ethics and the constitutional principle of integrity and efficiency

\footnotetext{
14 A. Błaś, J. Boć, J. Jeżewski, Administracja publiczna, Wrocław 2003, p. 277.

15 OJ EU C 83/389, 30.3.2010, https://bip.ms.gov.pl/Data/Files/_public/bip/prawa_czlowieka/onz/ karta.pdf (access: 6.7.2018).

16 T. Barankiewicz: Etyczne treści prawa do dobrej administracji, [in:] System prawa administracyjnego..., Vol. 13, p. 43.
} 
of public institutions. This relationship is a practical, but also normative proof of the importance of ethical reflection and the application of its effects in contemporary public administration. ${ }^{17}$

The concept of official ethics is related to the moral agent of the official service. The activities of administration are not based on anonymous and abstract bodies or other institutions. The subject of activities taken within the administration is a human person, characterised by specific qualifications, life experience, convictions, maturity, character traits and moral virtues. ${ }^{18}$ When entering the administration understood as an organisation, each employee brings with them a system of values related to their understanding of the public interest. This system of values can be shaped not only by standards resulting from the legal system, but also by non-legal factors, such as the influence of the immediate internal environment, experience acquired or the way of organising work, including the decision-making process. What is of major importance in this respect, however, is the education process related to raising qualifications.

The literature emphasises that it is not possible to codify all ethical standards of a public administration employee. It is necessary in this respect to apply general standards of moral law, first of all such as: do good, avoid doing evil, be truthful, make due sacrifice, be patient, be noble, provide help to other people, give advice, protect your dignity, do not disturb dignity of other people, be guided by trust in other people and at the same time prudence, do not humiliate another person, do not hurt other people, do not slander other people, do not be biased towards other people, do not be jealous of the other, forgive other people, do not hold a grudge, act in favour of other people, feel sorry for other people, think good about other people, show respect to other people, do not defame anyone, do not offend anyone, do not inspire evil, respect the privacy of other people, do not be rapacious, do not be greedy, do not buy goods to the detriment of the public or private interest, avoid the desire to control others, do not approve of evil, do not help in evil, do not lie, do not be angry, do not be selfish, control yourself, do not be envious, take care of the organisation's prestige rather than for your own prestige, be just. ${ }^{19}$ The indicated examples of moral law standards do not have to have their direct source in the regulations of administrative law. This does not mean, however, that they should not to be respected when implementing a function of public administration. One can cite

17 H. Izdebski: Etyka urzędnicza a zasada rzetelności i sprawności działania instytucji publicznych w demokratycznym państwie prawnym, [in:] System prawa administracyjnego..., Vol. 13, p. 61.

18 T. Barankiewicz: Urzędnika etyczne predyspozycje (cnoty), [in:] M. Domagała, A. Haładyj, S. Wrzosek (eds.), op. cit., pp. 287 et seq.

19 A. Błaś, J. Boć, J. Jeżewski, op. cit., pp. 276 et seq. 
a view here that there is a part of administrative law that is a set of standards or a set of demands that "introduce or could introduce into the administrative law universal values, that is, values beyond that law, necessary for its proper functioning". ${ }^{20}$ Therefore, there are important grounds to be guided in the administration not only by standards resulting directly from legal regulations. However, the question arises whether officials are aware of what ethics is in their actions? And this question raises the next one: Does the education system adequately prepare candidates for work in public administration, so that they are not guided only by passive implementation of the law?

\section{The role of higher education in the preparation of public administration staff}

Staff training for public administration at universities takes place primarily in the "administration" major. These are two-cycle studies. The first cycle, which is a bachelor's degree, lasts 3 years divided into 6 semesters. The second cycle, which is a master's degree, lasts 2 years divided into 4 semesters. Candidates who are graduates of the first cycle are admitted to the second cycle regardless of the study major they completed in the first cycle, or second cycle graduates or unified five-year studies in a different study major. This is not a fully advantageous solution for the preparation of human resources for public administration because candidates for second cycle studies in the "administration" major may not have basic knowledge in the field of legal sciences.

The next key study major preparing for work in public administration is "law". In this major, these can be unified Master's studies, which last 5 years divided into 10 semesters. However, more and more important are study majors in the "law with an adjective", e.g. economic law, law in business, and local government law. They are law studies, but do not give permission to take pupillage examinations, and consequently these studies do not provide opportunities to take up work in the legal professions (e.g. judge, attorney, prosecutor). Graduates from the majors defined as the "law with an adjective" represent a well-prepared and diverse group of candidates for work in public administration in terms of vocational preparation.

However, there is a significant drawback in education curriculums in study majors related to knowledge disciplines classified as legal sciences. This drawback is the underestimation of planning the effects of education related to shaping the personality of the employee, understanding the mission of public administration

20 J. Zimmermann, Prawo administracyjne, 8 ed., Warszawa 2018, p. 556. 
and knowledge of the principles of ethics, including official ethics, in the preparation of study curriculums. In the Ordinance of the Minister of Science and Higher Education of 26 September 2016 on second degree characteristics of the Polish Qualifications Framework typical for qualifications obtained in higher education after obtaining full qualification on level 4 - levels 6-821 (the Ordinance issued under the Act of 22 December 2015 on the Integrated Qualification System). ${ }^{22}$ In the Annex to the above-mentioned Ordinance (Second degree characteristics of the Polish Qualifications Framework typical for qualifications obtained in higher education after obtaining full qualification on level 4 - levels 6-8) the following learning outcomes were indicated in the category of knowledge in the field of education in social sciences: Level 6 (first cycle studies) - the graduate knows and understands traits of human as the creator of culture and an entity forming social structures and principles of their functioning (P6S_WG); Level 7 (second cycle studies and unified master's studies) - the graduate knows and understands deeply the traits of human as the creator of culture and an entity forming social structures and principles of their functioning (P7S_WG).

Targeted learning outcomes for study majors corresponding to disciplines classified as legal sciences resulting from regulations for qualifications obtained in higher education represent a weak basis for preparing graduates who will understand the importance and address non-legal aspects of work in public administration. Admittedly, these graduates are generally adequately prepared for analysing normative acts, issuing administrative decisions or understanding the rules of the legal system in general, but they lack the basis for addressing to a sufficient extent the issues related to ethics of acting and respecting the values adopted in the society. The study curriculums resign - in accordance with the requirements of the law - from the general academic profile in favour of a practical profile. Students are prepared to decide in specific cases, and university teachers more and more often do not convey general knowledge shaping the students' social attitudes. In order to change such a state of affairs, universities should strive to be able to prepare well-educated staff for public administration.

21 Journal of Laws of 2016, item 1594.

22 Journal of Laws of 2016, item 64 and 1010. 